\title{
The Effects of The Science Education Program based on Pedagogical Content Knowledge (PCK) of Kindergarten Teachers on Scientific Knowledge, Scientific Inquiry Skill, and Scientific Inquiry Attitude of Young Children in Korea
}

\author{
Rae-Eun Kim, Professor, Department of Social Welfare \& counselling, U1 University, Korea, \\ Versus486@u1.ac.kr \\ *Corresponding Author
}

\begin{abstract}
The purpose of this research was to analyze the effects of the science education program based on pedagogical content knowledge of kindergarten teachers on scientific knowledges, scientific inquiry skills, and scientific inquiry attitudes of young children in Korea. Research aimed to analyze the effect of science education program based on PCK of kindergarten teachers on young children' them. Research used a quasi-experimental non-equivalent control group design. The participants enrolled in this study were 36 five-year-old from S kindergarten in Busan City, in Korea. The data was analyzed with the analysis of covariance test using the SPSS 18.0 software. The results of the research are as fallows; the participating in this science education program based on PCK of kindergarten teachers showed significantly higher scores in scientific knowledges, scientific inquiry skills and scientific inquiry attitudes than those who participated in science activities from $\mathrm{Nu}$-Ri curriculum in Korea. In conclusion, it was confirmed that this science education program for young children based on PCK of kindergarten teachers improves young children's scientific knowledges, scientific inquiry skills, and scientific inquiry attitudes.
\end{abstract}

Keywords: young children, science education program, pedagogical contents knowledge, scientific knowledges, scientific inquiry skills, scientific inquiry attitudes

Received: 07.12.2020 Accepted: 08.01.2021

Published: 07.02.2021

\section{INTRODUCTION}

Cognitive activities of kindergarten teachers continue not only in the implementation of class, but also in the design and preparation of class. The more effective a teacher is, the more effort is spent on planning class than on teaching class. In other words, kindergarten teachers intentionally design and implement classes, which is embodied as pedagogical content knowledge in class. PCK is the knowledge that kindergarten teachers rely directly on when teaching their children. This knowledge is a personal "practical knowledge" implied by kindergarten teachers for teaching on a particular subject based on their diverse background knowledge and teaching beliefs and experiences [1].

"Teaching" is a very uncertain, dynamic and ever-changing complex process for kindergarten teachers [2]. Unlike the curriculum-based elementary teaching, early childhood education in the Republic of Korea operates based on a play-based integrated curriculum. It is very important for kindergarten teachers to have knowledge related to the overall understanding of the teaching environment, including knowledge about the integrated curriculum, early childhood knowledge, and teaching and learning methods.

In Korea, kindergarten teachers should refer to the national curriculum and decide their curriculum autonomously and run the curriculum flexibly. One of the areas of curriculum in which kindergarten teachers complain the most difficulties is the science field [3]. Despite the increased emphasis on teacher expertise in these science education [4], kindergarten teachers are unable to cope with young children appropriately due to the lack of systematic knowledge of science subjects and have difficulty in teaching science fields [3,5,6]. Korean young children also have lost their interest in the science field [5]. This phenomenon is not only due to the lack of scientific environment in the field of early childhood education, lack of scientific tools and instruments, lack of resources and finances, but also lack of understanding of the teacher's own scientific knowledge and science teaching methods, and negative attitudes such as scientific anxiety and lack of teacher's confidence [7,8,9].

The kindergarten teacher's PCK of science provides useful information to understand how they interpret and apply the science subjects that they understand. It also contains insightful information about the knowledge they use to teach. Prior studies on PCK emphasize PCK as a prerequisite for such 
competent and qualified teachers $[10,11]$. In this regard, the education society of Korea also explains the nature and scope of PCK in various fields from the point of view that PCK is an essential element for teacher professional development. Studies on the necessity of PCK extension for teachers in the scientific field $[12,13,14]$ have been conducted as well as studies on factors affecting teachers' PCK extension $[13,14]$.

Although PCK related studies have been conducted, most previous studies have focused on the identification of PCK characteristics $[15,16]$. Several studies have devised ways to represent PCK in order to understand the reality of PCK $[17,18]$, including the changes in PCK in teachers' classroom environments and the effects of these changes on teaching performance [19]. However, PCK-based program studies [20] are still scarce. In addition, these previous studies have limitations in explaining the PCK of early childhood teachers because teachers' PCK itself does not necessarily apply to their teaching practice.

In this regard, it requires a concrete understanding of the PCK of the kindergarten teacher. Through exploring the nature and components of PCK in science subjects, efforts are needed to analyze the process of formation and development of PCK or to embody this in science subjects. The higher the level of the PCK in the kindergarten teacher's science curriculum, the more likely the implementation of the science education program will positively affect the child's scientific knowledge, scientific inquiry skills, and scientific inquiry attitude. In other words, if the child's PCK in the science curriculum is assured and it is properly applied in the classroom, the science learning of young children will be done properly. Therefore, in this study, we developed an early childhood science education program based on kindergarten teacher's PCK, which can be easily and straightforwardly applied to early childhood science class. We attempted to verify the effects of the developed program on young children's scientific knowledges, scientific inquiry skills, and scientific inquiry attitudes.

The research questions of this were as follow:

1. Was there any effect of the science education program based on pedagogical content knowledge of kindergarten teachers on scientific knowledge of young children?

2. Was there any effect of the science education program based on pedagogical content knowledge of kindergarten teachers on scientific inquiry skill of young children?

3. Was there any effect of the science education program based on pedagogical content knowledge of kindergarten teachers on scientific inquiry attitude of young children?

\section{Experimental setup}

\subsection{Participants}

The participants enrolled in this study were 36 5-year-old from S kindergarten, located in Busan city. Classes were selected and assigned to the experimental group (18 5-year-old) and the control group (18 5 -year-old) in table 1. In order to maintain the homogeneity of the experimental group and the control group, both groups were to comprise of the same age children of the same kindergarten.

Table 1. Age distribution of experimental group and control group

\begin{tabular}{|l|l|l|l|l|l|l|}
\hline Division & N & $\begin{array}{l}\text { Male: } \\
\text { Female }\end{array}$ & Min. & Max. & M & SD \\
\hline Experimental group & 18 & $9: 9$ & 5.05 & 6.04 & 5.50 & .49 \\
\hline Control group & 18 & $9: 9$ & 5.05 & 6.04 & 5.45 & .47 \\
\hline Total & 36 & $18: 18$ & 5.05 & 6.04 & 5.47 & .47 \\
\hline
\end{tabular}

\subsection{Instruments}

\subsubsection{The Matrix System Model of PCK}

The matrix system model of the early childhood science education program based on PCK of kindergarten teachers, was developed by referring to the composition of the early childhood mathematics activity matrix based on pedagogical content knowledge and the questionnaire on recognition and actual condition of pedagogical content knowledge on the early childhood art activities. In addition, we referenced books, domestic journals and foreign journals related to scientific activities such as preceding studies related to early childhood science education program [21]. The matrix system model of the early childhood science education program based on PCK of kindergarten teachers is shown in Figure 1.

\begin{tabular}{|c|c|c|c|}
\hline Living subject & subject & Sub-topic & Activity date \\
\hline $\begin{array}{l}\text { Education } \\
\text { goal }\end{array}$ & Scientific knowledge & Scientific inquiry skill & $\begin{array}{l}\text { Scientific inquiry } \\
\text { attitude }\end{array}$ \\
\hline
\end{tabular}



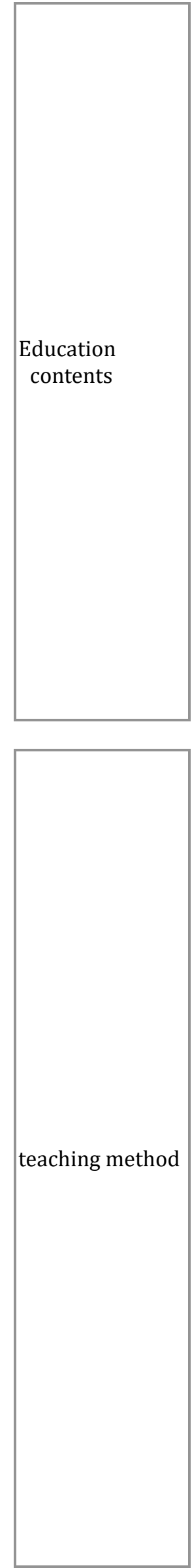

\begin{tabular}{|c|c|c|}
\hline \multicolumn{2}{|c|}{ Science topics } & \multirow{2}{*}{$\begin{array}{l}\text { Type of learning } \\
\text { zask } \\
\text { Fact Learning }\end{array}$} \\
\hline $\begin{array}{l}\text { Various } \\
\text { pbjects }\end{array}$ & Electricity & \\
\hline $\begin{array}{l}\text { Various } \\
\text { substances }\end{array}$ & Air & $\begin{array}{l}\text { Conceptual } \\
\text { learning }\end{array}$ \\
\hline Color & Sound & $\begin{array}{l}\text { Principle } \\
\text { learning }\end{array}$ \\
\hline Magnet & My body & $\begin{array}{l}\text { Procedure } \\
\text { Learning }\end{array}$ \\
\hline Heat & $\begin{array}{l}\text { Nature } \\
\text { material }\end{array}$ & $\begin{array}{l}\text { Learning of } \\
\text { Relationship } \\
\text { understanding }\end{array}$ \\
\hline Machine & Animal & $\begin{array}{l}\text { Problem solving } \\
\text { ability }\end{array}$ \\
\hline Tool & Plant & $\begin{array}{l}\text { Creative } \\
\text { thinking ability }\end{array}$ \\
\hline
\end{tabular}

\begin{tabular}{|c|c|}
\hline Inquiry skill & Inquiry attitude \\
\hline Observation & Curiosity \\
\hline Classification & Rationality \\
\hline Measurement & Objectivity \\
\hline Communication & $\begin{array}{l}\text { Reservation of } \\
\text { judgment }\end{array}$ \\
\hline Prediction & Criticality \\
\hline Inference & Openness \\
\hline \multirow[t]{5}{*}{ Generalization } & Honesty \\
\hline & $\begin{array}{l}\text { Humility and } \\
\text { conference }\end{array}$ \\
\hline & Cooperation \\
\hline & Accuracy \\
\hline & $\begin{array}{l}\text { Acceptance of } \\
\text { failure }\end{array}$ \\
\hline
\end{tabular}

\begin{tabular}{|l|l|}
\hline \multicolumn{2}{|l|}{ Type of activity } \\
\hline \multirow{4}{*}{$\begin{array}{l}\text { Grouping } \\
\text { strategy }\end{array}$} & Sarge group activities \\
\hline & Free choice activities \\
\hline \multirow{2}{*}{$\begin{array}{l}\text { Interactio group activities } \\
\text { n }\end{array}$} & Teacher-led \\
\hline & Young children-led \\
\hline & Teacher-children interaction \\
\hline
\end{tabular}

Environment for Scientific Activities Basic facility

Plant

Animal

Insect

Various objects and materials

Common tools and machine

Tools for measurement

Tool for safety

\section{Approach to Science Activities}

Heuristic approach

Approach to physical knowledge activity Representation \& discussion-centric approach

A literary approach

Multimedia approach

Natural exploration-centric approach
Time Planning of Science Activities Depending on the activity

Depending on the age

Conformity According to the level of young children

Depending on the time of activity

Activities

10-20 minutes

time

$31-40$ minutes

Pre-activity

This

\section{Introduction}




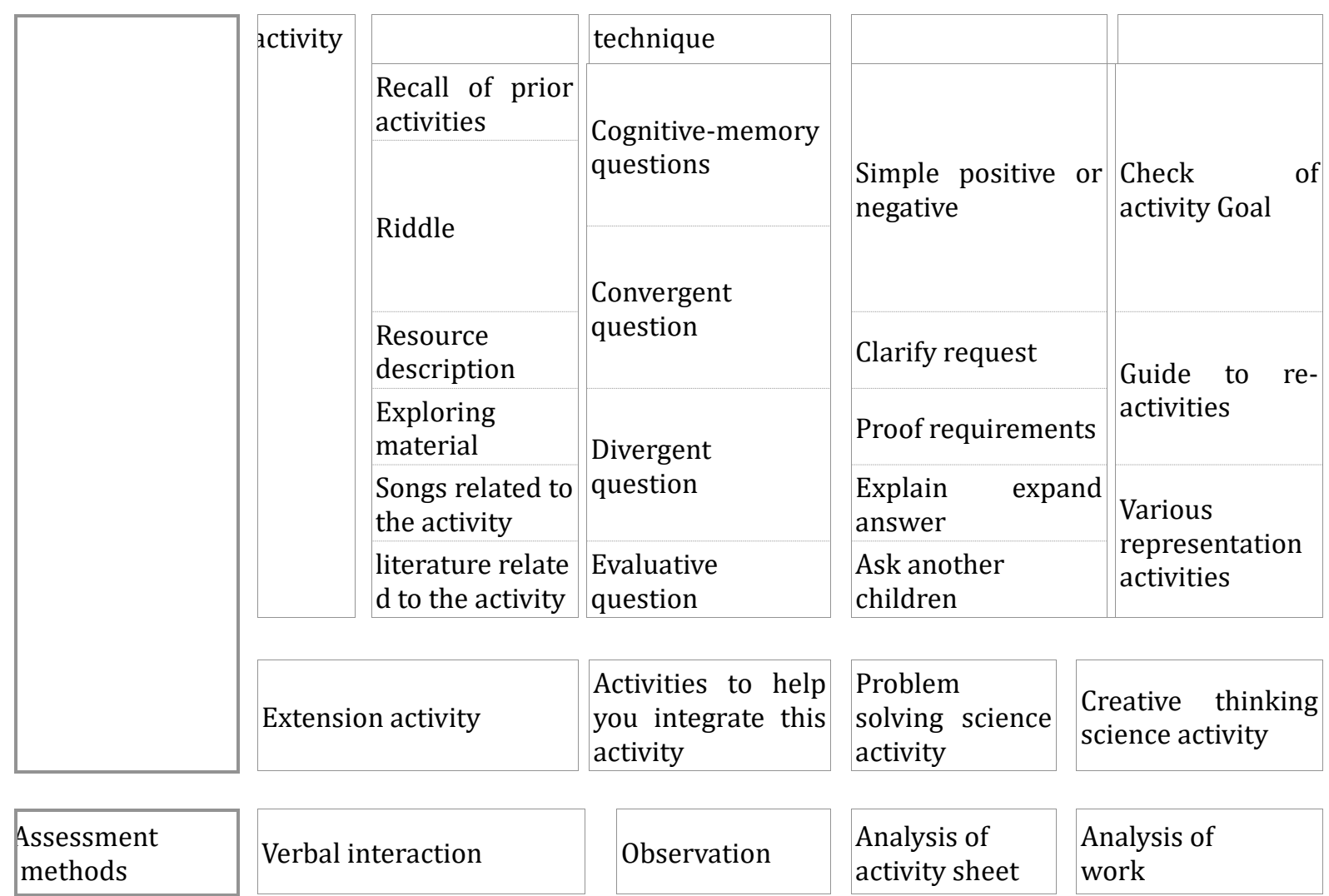

Figure 1. The matrix system model of early childhood science education program based on PCK of kindergarten teachers

\subsubsection{Instruments}

In order to measure the scientific knowledge, the topics and knowledge areas specified in the science area of the kindergarten curriculum were selected. The overall range of questionnaires and the questionnaires were determined. 'The scientific knowledge test' used by Lee and Han in 2010, in which two experts validate the content, was modified and supplemented for use in this study. In order to measure the knowledge of the curriculum, the scientific knowledge test consists of three fields - 'life and natural environment', 'objects and materials' and 'seasonal change', each of which has three questions so that a total of 9 questions were prepared for the test. In order to measure the scientific inquiry skills, 'the scientific inquiry skill test' that was supplemented based on Martin's scientific inquiry ability evaluation scale, was used in this study. A total of 25 questions including 7 subfields with five items of 'Observation', five items of 'Classification', four items of 'Measurement', five items of 'Discussion', two items of 'Prediction', two items of 'Inference', and two items of 'Generalization' were asked in this study. The reliability coefficient, Cronbach's $\alpha$ of scientific inquiry skills test were .82(.55 .69). In order to measure the scientific inquiry attitude, Martin's evaluation scale was revised and supplemented. The subfields of the scientific attitude test consist of nine components: curiosity, rationality objectivity, reservation of judgment, criticality, openness, honesty, Humility and conference, cooperation, accuracy and acceptance of failure. There are 27 questions in total, consisting of three questions in each sub-field. Reliability coefficients of scientific inquiry attitude subfactors were calculated from .48 to .68, and the reliability coefficient of the scientific inquiry attitude were .95 .

\subsection{Process}

The program was offered three or four times a week, and there were 18 total sessions. The experimental group was offered with18 activities for the science education program based on PCK of kindergarten teachers. On the other hand, the comparison group was treated 18 science activities based on $\mathrm{Nu}$-Ri curriculum in Korea.

\subsection{Analysis}

The data was analyzed by the SPSS 18.0 software. First, the reliability coefficient Cronbach's $\alpha$ coefficient was calculated and the Pearson correlation analysis was conducted to determine the reliability of the test device. Second, in order to verify the effectiveness of this program, the covariance analysis was conducted to control the difference of the post-scores between the experimental group and the control 
group after controlling the prior score of the two groups.

\section{Result Discussion}

3.1. The Effects of This Program based on PCK on Scientific Knowledges

Table 2 compared the adjusted scientific knowledges post-scores between the experimental group and the control group.

Table 2. The mean and standard deviation of post scores and adjusted post-score scores of scientific knowledges

\begin{tabular}{|c|c|c|c|c|c|c|}
\hline \multirow{2}{*}{\multicolumn{3}{|c|}{ Division }} & \multicolumn{2}{|c|}{$\begin{array}{l}\text { Post-scores } \\
\text { scientific } \\
\text { knowledges } \\
\text { subfactor }\end{array}$} & \multicolumn{2}{|c|}{$\begin{array}{l}\text { Adjusted post-scores } \\
\text { of scientific } \\
\text { knowledges } \\
\text { subfactor }\end{array}$} \\
\hline & & & $M$ & $S D$ & $M$ & $S D$ \\
\hline \multirow{8}{*}{$\begin{array}{l}\text { Life and } \\
\text { natural } \\
\text { environment }\end{array}$} & \multirow{2}{*}{ Fact } & Experimental group & 1.00 & .00 & 1.01 & .50 \\
\hline & & Control group & .83 & .38 & .82 & .50 \\
\hline & \multirow[t]{2}{*}{ Concept } & Experimental group & 1.28 & .58 & 1.24 & .12 \\
\hline & & Control group & .83 & .51 & .87 & .12 \\
\hline & \multirow[t]{2}{*}{ Rule } & Experimental group & .72 & .46 & .69 & .09 \\
\hline & & Control group & .28 & .46 & .31 & .09 \\
\hline & \multirow[t]{2}{*}{ Total score } & Experimental group & 3.00 & .77 & 2.94 & .16 \\
\hline & & Control group & 1.94 & .94 & 2.00 & .16 \\
\hline \multirow{8}{*}{$\begin{array}{l}\text { Objects } \\
\text { and materials }\end{array}$} & \multirow[t]{2}{*}{ Fact } & Experimental group & 1.00 & .00 & 1.00 & .08 \\
\hline & & Control group & .67 & .49 & .67 & .08 \\
\hline & \multirow[t]{2}{*}{ Concept } & Experimental group & 1.67 & .59 & 1.57 & .11 \\
\hline & & Control group & 1.11 & .58 & 1.21 & .11 \\
\hline & \multirow[t]{2}{*}{ Rule } & Experimental group & .33 & .49 & .34 & .09 \\
\hline & & Control group & .06 & .24 & .05 & .09 \\
\hline & \multirow{2}{*}{ Total score } & Experimental group & 3.00 & .84 & 2.90 & .18 \\
\hline & & Control group & 1.83 & .86 & 1.94 & .18 \\
\hline \multirow{8}{*}{$\begin{array}{l}\text { Natural } \\
\text { phenomenon }\end{array}$} & \multirow[t]{2}{*}{ Fact } & Experimental group & .94 & .24 & .96 & .07 \\
\hline & & Control group & .83 & .38 & .81 & .07 \\
\hline & \multirow[t]{2}{*}{ Concept } & Experimental group & 1.39 & .50 & 1.38 & .11 \\
\hline & & Control group & 1.00 & .49 & 1.01 & .11 \\
\hline & \multirow[t]{2}{*}{ Rule } & Experimental group & .83 & .38 & .82 & .10 \\
\hline & & Control group & .50 & .51 & .51 & .10 \\
\hline & \multirow[t]{2}{*}{ Total score } & Experimental group & 3.17 & .71 & 3.17 & .19 \\
\hline & & Control group & 2.33 & .97 & 2.33 & .19 \\
\hline \multirow{2}{*}{\multicolumn{2}{|c|}{$\begin{array}{l}\text { Overall } \\
\text { scientific knowledges }\end{array}$}} & Experimental group & 9.17 & 1.51 & 8.98 & .32 \\
\hline & & Control group & 6.11 & 1.75 & 6.30 & .32 \\
\hline
\end{tabular}

As shown in Table 2, the adjusted post scientific knowledges scores of the experimental group were higher than those of the control group. Table 3 shows the results of the covariance analysis on the scientific knowledges post scores between the experimental group and the control group.

Table 3. Covariance analysis of post scores of scientific knowledges between experimental group and control group

\begin{tabular}{|c|c|c|c|c|c|c|}
\hline \multicolumn{2}{|l|}{ Division } & \multirow{2}{*}{$\begin{array}{l}\text { Transformation } \\
\text { Pre-test } \\
\text { score(covariate) }\end{array}$} & \multirow{2}{*}{$\begin{array}{l}\begin{array}{l}\text { Sum of } \\
\text { squares }\end{array} \\
.81\end{array}$} & \multirow{2}{*}{$\begin{array}{l}\begin{array}{l}\text { Degrees } \\
\text { of } \\
\text { freedom }\end{array} \\
1\end{array}$} & \multirow{2}{*}{$\begin{array}{l}\begin{array}{l}\text { Mean } \\
\text { square }\end{array} \\
.81\end{array}$} & \multirow{2}{*}{$\begin{array}{l}\boldsymbol{F} \\
15.81^{* * *}\end{array}$} \\
\hline \multirow{6}{*}{$\begin{array}{l}\text { Life and } \\
\text { natural } \\
\text { environment }\end{array}$} & \multirow[t]{4}{*}{ Fact } & & & & & \\
\hline & & Group(main effect) & .31 & 1 & .31 & $6.05^{*}$ \\
\hline & & Error & 1.69 & 33 & .05 & \\
\hline & & Sum & 33.00 & 36 & & \\
\hline & \multirow[t]{2}{*}{ Concept } & $\begin{array}{l}\text { Pre-test } \\
\text { score(covariate) }\end{array}$ & 2.04 & 1 & 2.04 & $4.71^{* *}$ \\
\hline & & Group(main effect) & 1.15 & 1 & 1.15 & $4.71^{*}$ \\
\hline
\end{tabular}




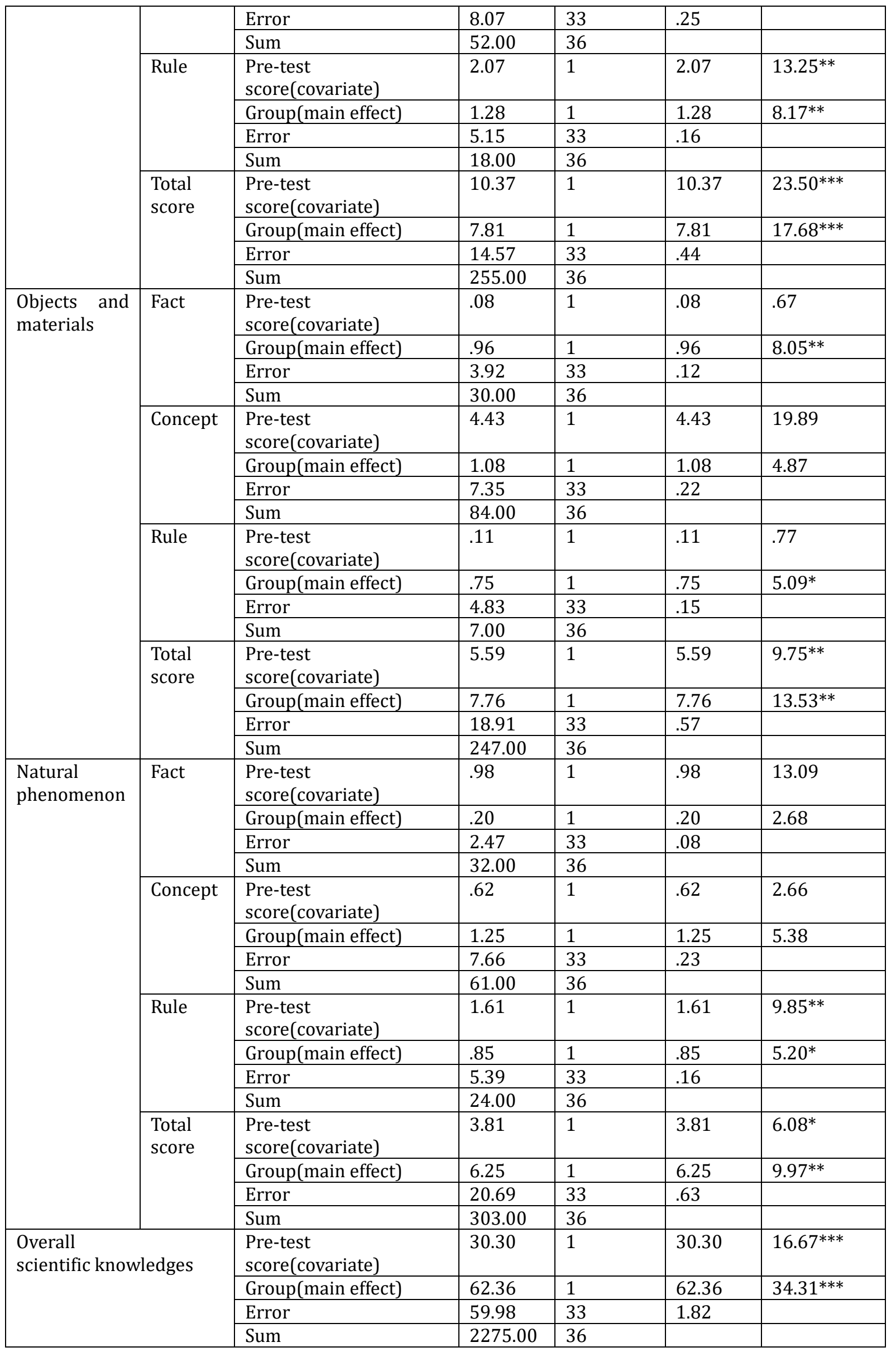


${ }^{*} p<.05,{ }^{* *} p<.01, * * * p<.001$

As shown in Table 4, the scientific knowledges post-scores showed a significant difference between the experimental group and the control group $(F=34.31, p<.001)$. The post-scores of life and natural environment $(F=17.68, p<.001)$, objects and materials $(F=13.53, p<.01)$, and natural phenomena $(F=9.97$, $p<.01$ ) showed significant differences between the experimental group and the control group.

The kindergarten teacher education program based on PCK has a positive effect on the acquisition of scientific knowledges such as life and natural environment, objects and materials, and natural phenomena of young children. This supports research results [10] that teachers with a lot of science pedagogy knowledges allows students to recognize the learning problem accurately and make full use of their knowledges in the classroom. In other words, an educational science program based on kindergarten teacher's PCK, is effective for the early childhood scientific knowledges formation. In this way, the children of the experimental group are gradually expanding their knowledges composition from prior knowledges to observation knowledges, constructing knowledges, and scientific knowledges through each activity of kindergarten teacher's PCK education.

\subsection{The Effects of This Program based on PCK on Scientific Inquiry Skills}

Table 4 compared the adjusted scientific inquiry skills post-scores between the experimental group and the control group.

Table 4. The mean and standard deviation of post-scores and adjusted post-scores of scientific inquiry skills

\begin{tabular}{|c|c|c|c|c|c|}
\hline \multicolumn{2}{|l|}{ Division } & \multicolumn{2}{|c|}{$\begin{array}{l}\text { Post-scores of scientific } \\
\text { inquiry skills } \\
\text { subfactor }\end{array}$} & \multicolumn{2}{|c|}{ 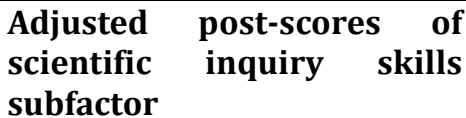 } \\
\hline & & $M$ & $S D$ & $M$ & $S D$ \\
\hline \multirow[t]{2}{*}{ Observation } & $\begin{array}{l}\text { Experimental } \\
\text { group }\end{array}$ & 17.28 & 1.53 & 17.34 & .28 \\
\hline & Control group & 16.22 & 2.10 & 16.16 & .28 \\
\hline \multirow[t]{2}{*}{ Classification } & $\begin{array}{l}\text { Experimental } \\
\text { group }\end{array}$ & 16.72 & 1.45 & 16.74 & .31 \\
\hline & Control group & 15.83 & 1.58 & 15.82 & .31 \\
\hline \multirow[t]{2}{*}{ Measurement } & $\begin{array}{l}\text { Experimental } \\
\text { group }\end{array}$ & 14.39 & 1.38 & 14.31 & .30 \\
\hline & Control group & 12.67 & 1.46 & 12.74 & .30 \\
\hline \multirow[t]{2}{*}{ Communication } & $\begin{array}{l}\text { Experimental } \\
\text { group }\end{array}$ & 16.72 & 1.57 & 16.55 & .36 \\
\hline & Control group & 15.17 & 1.86 & 15.34 & .36 \\
\hline \multirow[t]{2}{*}{ Prediction } & $\begin{array}{l}\text { Experimental } \\
\text { group }\end{array}$ & 7.28 & 1.07 & 7.25 & .23 \\
\hline & Control group & 6.33 & .84 & 6.36 & .23 \\
\hline \multirow[t]{2}{*}{ Inference } & $\begin{array}{l}\text { Experimental } \\
\text { group }\end{array}$ & 6.33 & 1.03 & 6.32 & .21 \\
\hline & Control group & 6.22 & .94 & 6.24 & .21 \\
\hline \multirow[t]{2}{*}{ Generalization } & $\begin{array}{l}\text { Experimental } \\
\text { group }\end{array}$ & 6.22 & .81 & 6.22 & .21 \\
\hline & Control group & 5.89 & .96 & 5.90 & .21 \\
\hline \multirow[t]{2}{*}{$\begin{array}{l}\text { Overall scientific } \\
\text { inquiry skills }\end{array}$} & $\begin{array}{l}\text { Experimental } \\
\text { group }\end{array}$ & 84.94 & 6.08 & 84.56 & 1.29 \\
\hline & Control group & 78.33 & 8.07 & 78.72 & 1.29 \\
\hline
\end{tabular}

As shown in Table 4, the adjusted post scientific inquiry skills scores of the experimental group were higher than those of the control group. Table 5 shows the results of the covariance analysis on scientific inquiry skills post scores between the experimental group and the control group. 
Table 5. Covariance analysis of post scores of scientific inquiry skills between experimental group and control group

\begin{tabular}{|c|c|c|c|c|c|}
\hline Division & Transformation & $\begin{array}{ll}\text { Sum } & \text { of } \\
\text { squares } & \end{array}$ & $\begin{array}{l}\text { Degrees } \\
\text { of } \\
\text { freedom }\end{array}$ & $\begin{array}{l}\text { Mean } \\
\text { square }\end{array}$ & $\boldsymbol{F}$ \\
\hline \multirow[t]{4}{*}{ Observation } & $\begin{array}{l}\text { Pre-test } \\
\text { score(covariate) }\end{array}$ & 68.05 & 1 & 68.05 & $48.11^{* * *}$ \\
\hline & Group(main effect) & 12.43 & 1 & 12.43 & $8.79^{* *}$ \\
\hline & Error & 46.67 & 33 & 1.41 & \\
\hline & Sum & 10225.00 & 36 & & \\
\hline \multirow[t]{4}{*}{ Classification } & $\begin{array}{l}\text { Pre-test } \\
\text { score(covariate) }\end{array}$ & 21.53 & 1 & 21.53 & $12.56^{* *}$ \\
\hline & Group(main effect) & 7.52 & 1 & 7.52 & $4.38^{*}$ \\
\hline & Error & 56.58 & 33 & 1.72 & \\
\hline & Sum & 9624.00 & 36 & & \\
\hline \multirow[t]{4}{*}{ Measurement } & $\begin{array}{l}\text { Pre-test } \\
\text { score(covariate) }\end{array}$ & 14.10 & 1 & 14.10 & $8.59 * *$ \\
\hline & Group(main effect) & 21.94 & 1 & 21.94 & $13.36^{* *}$ \\
\hline & Error & 54.18 & 33 & 1.64 & \\
\hline & Sum & 6683.00 & 36 & & \\
\hline \multirow[t]{4}{*}{ Communication } & $\begin{array}{l}\text { Pre-test } \\
\text { score(covariate) }\end{array}$ & 26.43 & 1 & 26.43 & $11.84^{* *}$ \\
\hline & Group(main effect) & 12.70 & 1 & 12.70 & $5.70^{*}$ \\
\hline & Error & 73.68 & 33 & 2.23 & \\
\hline & Sum & 9274.00 & 36 & & \\
\hline \multirow[t]{4}{*}{ Prediction } & $\begin{array}{l}\text { Pre-test } \\
\text { score(covariate) }\end{array}$ & .87 & 1 & .87 & .94 \\
\hline & Group(main effect) & 6.87 & 1 & 6.87 & $7.37^{*}$ \\
\hline & Error & 30.74 & 33 & .93 & \\
\hline & Sum & 1707.00 & 36 & & \\
\hline \multirow[t]{4}{*}{ Inference } & $\begin{array}{l}\text { Pre-test } \\
\text { score(covariate) }\end{array}$ & 6.05 & 1 & 6.05 & $7.37^{*}$ \\
\hline & Group(main effect) & .06 & 1 & .06 & .07 \\
\hline & Error & 27.07 & 33 & .82 & \\
\hline & Sum & 1452.00 & 36 & & \\
\hline \multirow[t]{4}{*}{ Generalization } & $\begin{array}{l}\text { Pre-test } \\
\text { score(covariate) }\end{array}$ & .32 & 1 & .32 & .40 \\
\hline & Group(main effect) & .91 & 1 & .91 & 1.13 \\
\hline & Error & 26.57 & 33 & .81 & \\
\hline & Sum & 1348.00 & 36 & & \\
\hline \multirow[t]{4}{*}{$\begin{array}{l}\text { Overall scientific } \\
\text { inquiry skills }\end{array}$} & $\begin{array}{l}\text { Pre-test } \\
\text { score(covariate) }\end{array}$ & 748.50 & 1 & 748.50 & $24.99^{* * *}$ \\
\hline & Group(main effect) & 304.90 & 1 & 304.90 & $10.18^{* *}$ \\
\hline & Error & 988.45 & 33 & 29.95 & \\
\hline & Sum & 242067.00 & 36 & & \\
\hline
\end{tabular}

\section{${ }^{*} p<.05,{ }^{* *} p<.01, * * * p<.001$}

As shown in Table 5, there was a significant difference between the experimental group and the control group in post-scores of scientific inquiry skills $(F=10.18, p<.01)$. Among sub-factors of scientific inquiry skills, the post-scores of observation $(F=8.79, p<.01)$, classification $(F=4.38, p<.05)$, measurement $(F=13.36, p<.01)$, communication $(F=5.70, p<.05)$ and prediction $(F=7.37, p<.05)$ showed the significant difference between experimental and control group, but post scores of inference $(F=.07, p$ $>.05)$ and generalization $(F=1.13, \mathrm{p}>.05)$ showed no significant difference between the experimental group and the control group.

Early childhood science education program based on PCK of kindergarten teachers has a positive effect on the improvement of scientific inquiry skills of young children. Our results are in the same context as the results of several previous studies. For example, integrated activities that combine drawing and 
science activities using various expression methods [22], integrated activities of aesthetic and scientific inquiry elements [23], the early childhood science education program using mathematical representation [24], science and art convergence education activities using fairy tales [25] have positive effects on young children's scientific inquiry skills. On the other hand, kindergarten teacher's PCK-based early childhood science education programs had no effect on inference and generalization. Reasoning requires very abstract thinking and is not as simple as 'prediction' so that it is still difficult to judge the authenticity of young children's reasoning. In addition, generalization refers to young children's learning of a scientific principle or law and applying it to every life or other activities. Eighteen sessions of scientific activities may not be sufficient to gauge the effect of this scientific inquiry function. Since the scientific inquiry skills are not formed suddenly at any moment, it is composed through continuous process of experiencing cognitive conflict in daily life and searching for solutions or alternatives.

\subsection{The Effects of This Program based on PCK on Scientific Inquiry Attitudes}

Table 6 compared the adjusted scientific inquiry attitudes post-scores between the experimental group and the control group.

Table 6. The mean and standard deviation of post-scores and adjusted post-scores of scientific inquiry attitudes

\begin{tabular}{|c|c|c|c|c|c|}
\hline \multicolumn{2}{|l|}{ Division } & \multicolumn{2}{|c|}{$\begin{array}{lr}\begin{array}{l}\text { Post-scores of } \\
\text { inquiry }\end{array} & \begin{array}{r}\text { scientific } \\
\text { attitude } \\
\text { subfactor }\end{array}\end{array}$} & \multicolumn{2}{|c|}{$\begin{array}{l}\text { Adjusted Post-scores of } \\
\text { scientific inquiry attitude } \\
\text { subfactor }\end{array}$} \\
\hline & & $M$ & $S D$ & $M$ & $S D$ \\
\hline \multirow[t]{2}{*}{ Curiosity } & Experimental group & 10.33 & 1.24 & 10.39 & .21 \\
\hline & Control group & 9.44 & 1.38 & 9.38 & .21 \\
\hline \multirow[t]{2}{*}{ Rationality } & Experimental group & 10.00 & 1.09 & 10.00 & .22 \\
\hline & Control group & 9.00 & 1.33 & 9.00 & .22 \\
\hline \multirow[t]{2}{*}{ Objectivity } & Experimental group & 10.22 & 1.00 & 10.22 & .21 \\
\hline & Control group & 8.89 & 1.37 & 8.89 & .21 \\
\hline \multirow{2}{*}{$\begin{array}{l}\text { Reservation of } \\
\text { judgment }\end{array}$} & Experimental group & 10.11 & 1.08 & 10.16 & .23 \\
\hline & Control group & 8.94 & 1.11 & 8.90 & .23 \\
\hline \multirow[t]{2}{*}{ Criticality } & Experimental group & 10.11 & 1.28 & 10.07 & .27 \\
\hline & Control group & 9.06 & 1.26 & 9.09 & .27 \\
\hline \multirow[t]{2}{*}{ Openness } & Experimental group & 10.17 & 1.04 & 10.15 & .20 \\
\hline & Control group & 8.78 & 1.06 & 8.79 & .20 \\
\hline \multirow[t]{2}{*}{ Honesty } & Experimental group & 10.28 & 1.18 & 10.30 & .24 \\
\hline & Control group & 9.11 & 1.08 & 9.08 & .24 \\
\hline \multirow{2}{*}{$\begin{array}{l}\text { Humility and } \\
\text { conference }\end{array}$} & Experimental group & 6.67 & .84 & 6.77 & .19 \\
\hline & Control group & 5.89 & .96 & 5.79 & .19 \\
\hline \multirow[t]{2}{*}{ Cooperation } & Experimental group & 10.22 & 1.22 & 10.28 & .25 \\
\hline & Control group & 8.83 & 1.15 & 8.78 & .25 \\
\hline \multirow[t]{2}{*}{ Accuracy } & Experimental group & 10.33 & 1.14 & 10.36 & .28 \\
\hline & Control group & 8.94 & 1.39 & 8.92 & .28 \\
\hline \multirow{2}{*}{$\begin{array}{l}\text { Acceptance of } \\
\text { failure }\end{array}$} & Experimental group & 9.83 & 1.10 & 9.89 & .25 \\
\hline & Control group & 8.83 & 1.04 & 8.77 & .25 \\
\hline \multirow{2}{*}{$\begin{array}{l}\text { Overall scientific } \\
\text { inquiry attitudes }\end{array}$} & Experimental group & 108.28 & 9.46 & 108.75 & 1.70 \\
\hline & Control group & 95.72 & 10.69 & 95.25 & 1.70 \\
\hline
\end{tabular}

As shown in Table 6, the adjusted post scientific inquiry attitudes scores of the experimental group were higher than those of the control group. Table 7 shows the results of covariance analysis on post scores of scientific inquiry attitudes between the experimental group and the control group.

Table 7. Covariance analysis of post scores of scientific inquiry attitudes between experimental group and control group

\begin{tabular}{|l|l|l|l|l|l|}
\hline Division & Transformation & $\begin{array}{l}\text { Sum of } \\
\text { squares }\end{array}$ & $\begin{array}{l}\text { Degrees of } \\
\text { freedom }\end{array}$ & Mean square & $\boldsymbol{F}$ \\
\hline Curiosity & $\begin{array}{l}\text { Pre-test } \\
\text { score(covariate) }\end{array}$ & 32.34 & 1 & 32.34 & $40.88^{* * *}$ \\
\hline
\end{tabular}




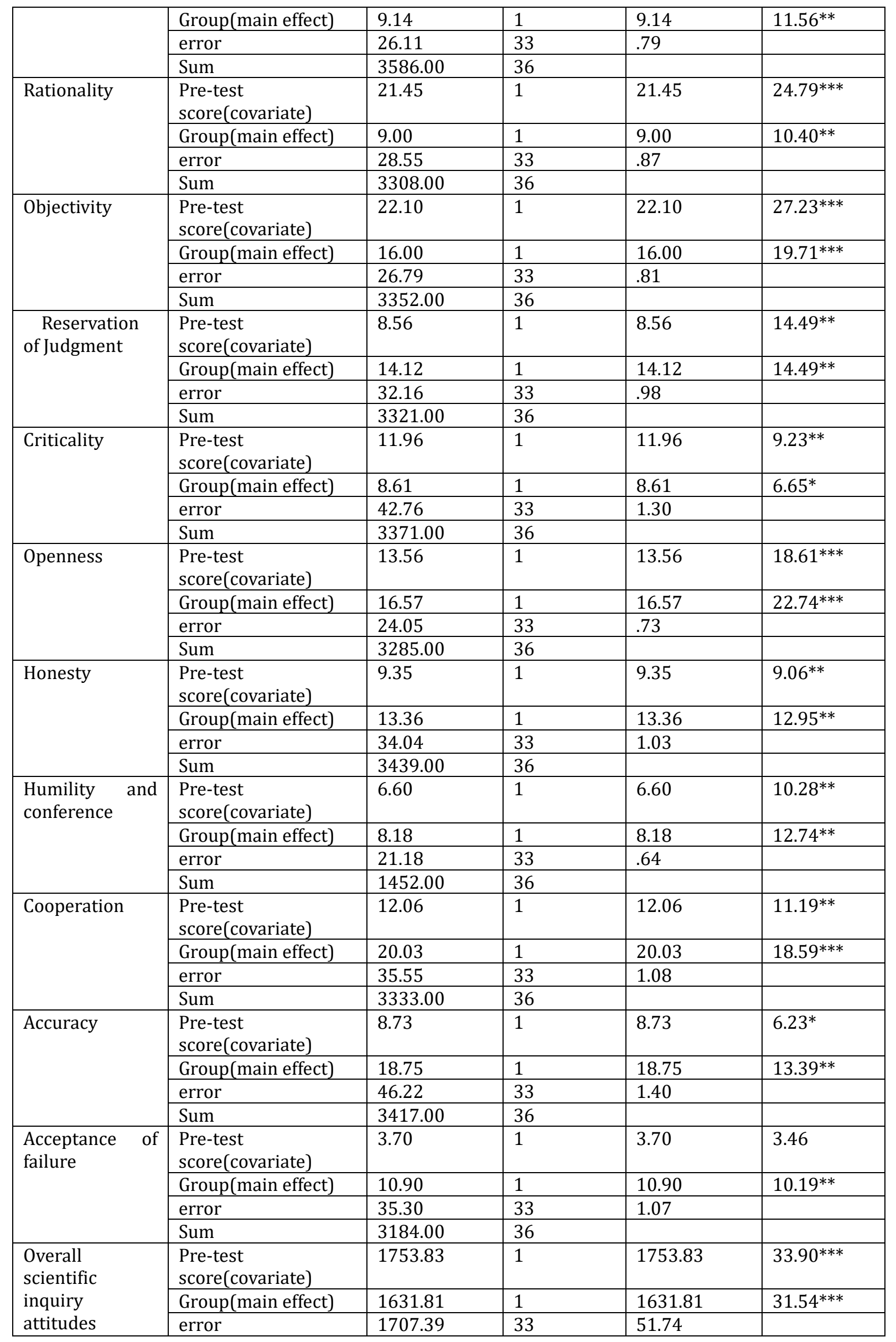


As shown in Table 7, there was a significant difference between the experimental group and the control group in the post scores of scientific inquiry attitudes $(F=31.54, p<.001)$. The post scores of the curiosity $(F=11.56, p<.01)$, rationality $(F=10.40, p<.01)$, objectivity $(F=19.71, p<.001)$, reservation of judgment $(F=14.49), p<.01)$, criticality $(F=6.65, p<.05)$, openness $(F=22.74, p<.001)$, honesty $(F=12.95$, $p<.01)$, humility and conference $(F=12.74, p<.01)$, cooperation $(F=18.59, p<.001)$, accuracy $(F=13.39, p$ $<.01)$ and acceptance of failure $(F=10.19, p<.01)$ were significantly different between the experimental group and the control group.

The result of this study supports the following previous research; the integrative activities of aesthetic and scientific inquiry elements [23], the early childhood science education program based on creativity techniques [21], and the early childhood science education program based on the maker education [26] have positive effects on scientific inquiry attitudes of young children. Scientific inquiry attitudes formed during early childhood help predict behaviors related to science, and scientific inquiry attitudes formed during early childhood affect the interest in science throughout life. Since the scientific inquiry attitudes of young children is formed much earlier than other subjects, it is very important to provide science education that can develop their scientific inquiry attitudes in early childhood in order to develop a positive attitude to science education later. Therefore, it is necessary to consider the scientific inquiry attitudes when constructing an early childhood science education program based on PCK of kindergarten teachers.

\section{Conclusions}

The implications of this study are as follows. First, in order to reinforce kindergarten teacher's classroom design and execution capacity through PCK, it is necessary to devise ways to strengthen their science school PCK. Therefore, in order to develop the PCK of kindergarten teachers, it is necessary to systematically explore the practical knowledge made by the teachers who teach the early childhood and share their practical knowledge among the teachers. In other words, we propose class consulting or professional learning community for the science subject PCK that exposes, specifies and shares the science subject PCK possessed by the experienced teacher through the actual young children science class conducted in the early childhood education field. Second, a plan for the development of science school PCK for preservice kindergarten teachers should be provided. Preservice teacher education tends to focus on the content knowledge of each subject. The PCK should be developed into a class to raise an eye to consider the level of preservice teachers and the level required in the curriculum.

In conclusion, the implications of this study are as follows: First, the theoretical basis for the basic concepts, characteristics, and elements of science subject PCK for Korean kindergarten teachers was provided. Basic materials were also provided to help study the composition, approach, and teaching and learning methods of science education programs for young children. Second, the practical science education program based on PCK of kindergarten teachers developed in this study is an effective teaching and learning method that can improve young children's scientific knowledge, inquiry ability and inquiry attitude. The possibility of active application is presented. The potential application in the real educational field is presented. Third, educationally, this study provided basic materials for developing the programs and curriculum for kindergarten teacher education in early childhood nurturing institutes responsible for early childhood education and for science education training and conservative education.

\section{Acknowledgements}

This study was prepared from a part of doctoral thesis of department of Early Childhood Education at Kyungsung University under the supervision of Professor Hong, S. O.

\section{References}

[1] Shulman L. S. (1986) Those who understand: Knowledge growth in teaching. Educational Research, 15(2), 4-14.

[2] Spiro R. J., Coulson R. L., Feltovich P. J. and Anderson D. K. (1988) Cognitive flexibility theory: Advanced knowledge acquisition in ill-structured domains. Paper presented at the tenth annual conference of the cognitive science society. Hilldale, New Jersey: Erlbaum. 
[3] Lee K. M. (2000) A study of the science education based on the interactive approach on preschool children's scientific concepts, process skills, and attitude. Seoul: Chung-Ang University.

[4] Wenglinsky H. (2000) How Teaching Matters: Bringing the Classroom Back into Discussions of Teacher Quality. Princeton, NJ: Educational Testing Service.

[5] Kang H. H. (2003) A study on the attitudes toward science education of early childhood pre-service teachers. Seoul: Chung-ang University.

[6] Song Y. S. and Hwang H. I. (2004) A study of changes in preservice early childhood teachers' scientific knowledge. The Korean Journal of Early Childhood Education Research, 24(2), 87-105.

[7] Cho B. K. and Suh S. Y. (2001) Self-efficacy beliefs of kindergarten science teachers. Korean journal of child studies, 22(2), 361-373.

[8] Kang E. J. (2008) The relationship between kindergarten teachers' science teaching efficacyand science teaching attitude. Seoul: Myongji University.

[9] Lee K. M. (2004) An investigation of science anxiety of kindergarten teachers. Journal of Future Early Childhood Education, 12(1), 385-406.

[10] Im C. H. (2003) Nature and development of pedagogical content knowledge in science teaching. Journal of the Korean Earth Science Society, 24(4), 235-249.

[11] Ball D. and MacRiarmid G. (1990) The subject matter preparation of teachers. In W. Houston, M. Haberman, and J. Sicula (Eds.), Handbook of Research on Teacher Education. New York: MacMillan.

[12] Kim H. J. (2007) Development of assessment tools for kindergarten teachers' pedagogical content knowledge of science teaching. Seoul: Duksung Women's University.

[13] Im C. H. (2003) Science teaching practice and science teaching efficacy beliefs by development of elementary school teachers' pedagogical content knowledge. Journal of the Korean Earth Science Society, 24(4), 258-272.

[14] Cho B. K. and Lee E. J. (2007) A study on the variables influencing kindergarten teachers' pedagogical content knowledge in science. The Journal of Korea Open Association for Early Childhood Education, $12(1), 185-205$.

[15] Carlsen W. S. (1999) Domain of teacher knowledge. In J. Gess-Newsome and N. G. Lederman (Eds.), Examining Pedagogical Content Knowledge. Boston: Kluwer Academic Publishers.

[16] Grossman P. L. (1990) The making of a teacher: Teacher knowledge and teacher and education. New York: Teachers College Press.

[17] Hashweh M. A. (2005) Teacher pedagogical constructions: A reconfiguration of pedagogical content knowledge. Teachers and Teaching: Theory and Practice, 11(3), 273-292.

[18] Gess-Newsome J. and Lederman N. G. (1993) Preservice biology teachers' knowledge structures as a function of professional teacher education: A year-long assessment. Science Education, 77(1), 25-45.

[19] Mulholland J. and Wallace J. (2005) Growing the tree teacher knowledge: ten years of learning to teach elementary science. Journal of Research in Science Teaching, 42(7), 767-790.

[20] Kwak H. R. (2005) A Study of Scientific Contents Knowledge and Knowledge Construction on Pendulum in a Constructivist Classroom. The Korean Journal of Early Childhood Education Research, 25(5), 227-250.

[21] Im G. J. and Kim Y. O. (2012) Development and effectiveness of early childhood science education program with creativity techniques. Early Childhood Education Research \& Review, 16(1), 523-549.

[22] Park H. S. (2019) A study on developing and applying the science-art convergence education program for young children based on the storytelling. Journal of Learner-Centered Curriculum and Instruction, 19(11), 119-139.

[23] Ji S. A., Kim N, H., Sim H. J., Lee S. M. and Sim J. Y. (2009) The Effect of the Integrated Activity with Art and Science on Young Children's Scientific Inquiry Competence, Scientific Attitude, Spatial Ability and Representation Ability. Early Childhood Education Research \& Review, 13(5), 307-330.

[24] Kim D. R. and Chung M. R. (2018) The development and effects of the science education program for young children using mathematical representation. The Korean Journal of Early Childhood Education Research, 38(5), 179-209.

[25] Park H. S. (2019) A study on developing and applying the science-art convergence education program for young children based on the storytelling. Journal of Learner-Centered Curriculum and Instruction, 19(11), 119-139.

[26] Cho K. M. and Lee Y. S. (2018) The development and effects of an early childhood science education program based on maker education. The Korean Journal of Early Childhood Education Research, 38(1), 341-365. 